\title{
1. Towards corporate self-regulation
}

It is hard to imagine a world without multinational corporations (MNCs). ${ }^{1}$ They provide much-needed goods and services, undertake invaluable research and development, and coordinate most of the world's trade and investment. Without them, it would be impossible to telephone family and friends overseas, travel to new and exotic destinations, watch global events on television, or indulge in life's many luxuries. Indeed, if MNCs did not exist, our life experiences would be truncated, localised and, in all probability, quite miserable. But when they spill toxic chemicals into our rivers, pollute the atmosphere, defraud investors, and are linked to mercenary groups and wicked dictatorships, critics are right to question whether they do more harm than good.

When challenged about their activities, MNCs have often claimed that their sole purpose is to maximise shareholder value. They exist to make a profit, and return a portion of that profit to those individuals who have a financial stake in the success of the company. In order to live up to this commitment, it is sometimes necessary for them to engage in socially questionable ventures, such as mining on traditional lands or logging old-growth forests. Friedman (1970: 126) famously articulates this view when he suggests that ' $[t]$ here is one and only one social responsibility of business - to use its resources and engage in activities designed to increase its profits so long as it stays within the rules of the game, which is to say, engages in open and free competition without deception or fraud'. But, as Schwartz and Gibb (1999: 59) perceptively point out, many MNCs have sought to maximise shareholder value by playing outside the rules of the game, that is, by operating in what they call the 'gray area'.

Friedman's defence of the function of the corporation in society is no longer convincing, nor is it providing much of a safeguard for MNCs against criticism of their behaviour. Governments are displaying a greater willingness to punish companies for criminal and regulatory breaches. Activist groups are more adept than ever at mounting powerful and embarrassing protest campaigns. The global media have also shown a fondness for highlighting corporate crime, despite themselves being large 
MNCs. And, as the experience of News of the Day in Great Britain demonstrates, even large media organisations are not immune from crisis.

Members of the general public, too, are standing up to MNCs. ${ }^{2}$ In Australia, farmers are protesting against coal seam gas (CSG) exploration on their properties, while a number of coastal communities in Queensland are opposing development projects that may impact on the local marine environment, especially around the Great Barrier Reef.

There are numerous other examples of civil society groups who have 'bested' MNCs. The issue of control over the water supply in Cochabamba, Bolivia, is one of the most recent examples of a successful protest against a large MNC. Dangl's (2007) account of this protest is a powerful reminder that ordinary people can effect meaningful change in the societies in which they live. ${ }^{3}$

Over the last decade, and in response to pressure from activist groups, many MNCs have been reinventing (and rebranding) themselves as socially responsible, environmentally sensitive actors. This has resulted in the emergence of a range of new corporate strategies for addressing community concerns. ${ }^{4}$

Royal Dutch Shell is one of the first MNCs to rethink its business model. ${ }^{5}$ Others, like The Body Shop, have been remarkably successful in committing to an ethical approach to business. Even those MNCs with a poor ethical track record in the past have begun to promote themselves as good corporate citizens. Nike, a company associated with sweatshops, exploited labour and human rights violations, has stated that it is working to transform community perception of its business activities as immoral. The company is now a signatory to the United Nations Global Compact (UNGC) (Fisher and Lovell, 2006: 495). It has also founded a not-forprofit foundation to further development goals in the poorer countries of the world. Specifically, the Nike Foundation focuses its attention on improving the welfare of adolescent girls. The programme is called The Girl Effect (n.d.).

The mission statement of the organisation is called the Girl Declaration. It includes five goals and seven principles to improve the lives of young women. As the organisation's website notes:

Girls were left out of the original Millennium Development Goals. The Girl Declaration has been written to make sure that doesn't happen again. Bringing together the thinking of 508 girls living in poverty across the globe with the expertise of more than 25 of the world's leading development organizations, the Girl Declaration is our tool to stop poverty before it starts. 
Given that there are as many as 600 million adolescent girls living in poverty worldwide, Nike's commitment is symbolic, and could easily be read as a cynical attempt to tie the company to an important global social issue. Indeed, it is possible to argue that the company had learnt nothing from its sweatshops crisis. Instead of exploiting young women in its sweatshops in Asia, it is now exploiting 508 girls to demonstrate to the world that it is a responsible, caring company. What the Nike project highlights, though, is the extent to which companies are now seeking to engage with important social issues. This is indeed a revolution in corporate behaviour.

Jackson (2004: 21) argues that we are witnessing the emergence of a new paradigm in international business. At the heart of this paradigm is what he calls the 'business integrity thesis'. This thesis suggests that, while investors want to see financially profitable enterprises, they also want companies to engage in environmentally and socially responsible conduct. According to him, the engine driving this paradigm shift is the corporate reputation. This has become the most prized commodity of MNCs in an era of globalisation.

If a concern with corporate reputation is the engine driving this new business paradigm, it is activist groups that have fanned the flame of change (Nace, 2005: 197-218; Manheim, 2002). ${ }^{6}$ Business advocate Peters (1999) observes that these groups have discovered that they could 'name and shame' offending companies and, in so doing, affect their reputations in the marketplace (Skeel, 2005; Bartley and Child, 2010). ${ }^{7}$ Peters likens these groups to prehistoric velociraptors. He argues (1999: 1) that '[ $t]$ he Velociraptor was among creation's most ferocious predators, and its killer instincts live on in the form of well-intentioned but deadly activist groups ready to shred and devour your company's reputation'.

I call this broad group of dissenters 'anti-corporate activists'. The identifiable characteristics of anti-corporate activists are first, an opposition to what they call 'corporate rule'. By this, they mean that the international community has allowed MNCs to gain control over the political and economic processes of international politics. Anti-corporate activists seek to overturn this state of affairs. As Danaher and Mark (2003: 1) note: '[a]n insurrection against corporate rule is underway'. Second, they are fiercely opposed to capitalism, neoliberalism and globalisation. While these are interwoven concepts, anti-corporate activists see these ideas as the philosophical, political and economic foundation of MNC power. Finally, they are the group most dangerous to the interests of MNCs. Manheim and Holt argue that anti-corporate activists pose an 'existential threat' to MNCs. As they (Manheim and Holt, 2013: 430) note: 'It is anticorporate campaigners, not labor activists, who hang 
by ropes from bridges and buildings to garner attention, anticorporate campaigners, not activist investors, who challenge legislatures to rescind corporate charters'.

The arguments of anti-corporate activists are most clearly articulated in Mander and Goldsmiths' The Case Against the Global Economy (1996); Karliner's Corporate Planet (1997); Korten's When Corporations Rule the World (2001); Danaher and Mark's Insurrection (2003); Bakan's The Corporation (2005); Willis and Hardcastle's The I Hate Corporate America Reader (2004); and Derber's Corporation Nation (2014). The sentiment flowing from these works can be summed up crudely by Willis and Hardcastle (2004: ix-x).

Corporations exert a troubling influence - make that horrifying - degree of control over every aspect of our lives: our work, our play, our entertainment, our health care, our food supply, our transportation, our environment, our government ... Hmmm. You know what? We think we're getting fucked - and so are you. ${ }^{8}$

Other well-known voices in this space include Noam Chomsky, Noreena Hertz, George Monbiot, Gore Vidal, Howard Zinn, Michael Moore, John Pilger, Vandana Shiva, Naomi Klein and Tariq Ali. These are highly politicised opponents of MNCs, and fair and reasoned argument is sometimes less important than the moral rhetoric necessary to get their point across (O'Callaghan, 2007b). We can get some idea of this rhetoric from a passage from Korten's well-known book. He (2001: 22) suggests that globalisation has:

[t]ransformed once beneficial corporations and financial institutions into instruments of a market tyranny that reaches across the planet like a cancer, colonizing ever more of the planet's living spaces, destroying livelihoods, displacing people, rendering democratic institutions impotent, and feeding on life in an insatiable quest for money.

Whether one agrees with the provocative nature of this sentiment or not, I argue that anti-corporate activists have been instrumental in pushing MNCs to embrace a new and more ethical approach to business.

Their negative critique of MNCs has been very successful - up to a point. Anti-corporate activists have managed to turn the corporate reputations of MNCs into a political issue. At the same time, I argue that their inability to move beyond a negative ideological critique has now blunted much of the force of their attacks. This is not to say that they are irrelevant. They simply do not understand the extent of the shift in MNC behaviour that is taking place today. Nor do they understand how important they have been in driving this agenda. 
The chapter is divided into four sections. The first section discusses the four main criticisms that anti-corporate activists level at MNCs. There are other issues, but these dominate the debate. The second section looks at the rise and fall of anti-corporate activist power over the last decade or so. The third section examines how international institutions are adding their voice to this important debate. The final section explores the 'politicisation' of the corporate reputation. It employs the social amplification of risk framework (SARF) to explain theoretically why anticorporate activists have been so successful in getting their negative message about MNCs across. Put simply, as a consequence of globalisation, anti-corporate activists have become adept at communicating risk to the public. By painting MNCs as a threat, they increase the degree of fear about them in the broader community. This novel tactic has led to MNCs taking the challenge of anti-corporate activists more seriously than ever before. As a result, MNCs are responding in novel ways to this challenge. Some of these strategies I discuss further in the case study chapters. This chapter concludes by suggesting that MNCs are now moving toward corporate self-regulation as a means of dealing with anti-corporate activist pressure, as well as that emanating from international institutions such as the United Nations (UN). In short, corporate reputation is having a disciplining affect on MNC behaviour. As a consequence, we are entering a new period in business-society relations. The corporate reputation is now calling the shots in this debate.

\section{MNCS IN THE CROSS-HAIRS}

MNCs are commercial enterprises that carry out profit-making activities in more than one country (Griffiths et al., 2014: 224). The definition of an MNC is contested. O'Brien and Williams (2010: 188) note that '[m]ost writers make no distinction between these terms and have settled for one terminology rather than another without any seeming reflection on the implications of these terms'. 9 They acknowledge, however, that the term 'multinational corporation' (MNC) is most commonly used in the international political economy literature, and that trend is continued here.

The last decade or so has seen a remarkable increase in the number of MNCs. In 1998, the UN estimated that there were over 53000 MNCs operating around the world. In addition, another 450000 foreign affiliates had commercial relationships with these companies (Kegley and Wittkopf, 2004: 226). By 2007, that number had increased dramatically. According to the 2007 World Investment Report (UNCTAD, 2007) that 
number had increased to 77175 , and these parent companies owned more than 773000 commercial affiliates (Kegley and Blanton, 2009: 205).

Some MNCs now have larger revenues than many sovereign states. In 2007, ExxonMobil had revenues of US\$390.32 billion and the company made a staggering US\$40.6 billion profit (ExxonMobil, 2007: 4). In 2010 , with a drop in the price of oil, profits fell to a modest US\$37.012 billion (ExxonMobil, 2010: 10). In 2013, the company rebounded with US $\$ 420.83$ billion in revenues and made a profit of US\$33.44 billion (ExxonMobil, 2013). This is larger than the gross national income (GNI) of Norway, the Philippines and South Africa. Similarly, according to Walmart's (2014) most recent annual report, the company earned revenues totalling US\$476.29 billion and made US\$16.022 billion profit.

Anti-corporate activists never tire of highlighting how this wealth is (mis)used to advance the interests of MNCs, at the expense of local communities. They level a number of criticisms at MNCs. While these are expressed in various ways, they can be distilled into four key concerns. First, MNCs have excessive power and influence over national governments. This power undermines democracy. Second, they have a poor human rights record. Third, they pollute the environment. Fourth, they weaken traditional cultures and promote cultural homogenisation. ${ }^{10} \mathrm{I}$ examine each of these issues in turn.

\section{They Have Excessive Power and Influence}

MNCs evaluate political risk as a matter of course. Countries that have a stable political environment are generally more preferable sites for investment than those that are unstable, prone to spontaneous changes of government and policy direction, and where the obsolescing bargain may occur (Vernon, 1971; Vivoda, 2008). ${ }^{11}$ However, the type of political system governing the host country is a much less important factor. MNCs can operate as easily in an authoritarian country as they can in a representative democracy. The mining company Freeport McMoRan has had a strong relationship with the Suharto regime in Indonesia (Waldman, 1998). This began in the late 1960s, and continued until Suharto stepped down from power in 1998 (Leith, 2002). In this sense, MNCs are moral relativists; they rarely make ethical judgements about the merits of one political system over another, or the merits of a particular government. They are often on record as stating that, as a matter of corporate policy, they do not interfere in the domestic affairs of the countries in which they operate. ${ }^{12}$

For anti-corporate activists, this is a difficult argument to accept. The moment an MNC begins to negotiate with a host government for a 
licence to operate (LTO), it enters into a dialogue that has political consequences and outcomes. For example, tax breaks reduce government revenue, which has an impact on the distribution of goods and services to local communities. An agreement between a host country and an MNC to mine a tract of land may infringe on the rights of traditional landowners. Most large MNCs are also members of host country chambers of commerce and various industry groups. The express purpose of these organisations is to lobby governments on behalf of their members. MNCs may not be directly involved in these negotiations, but membership amounts to a de facto involvement in the political process, as these organisations actively seek to influence public policy for the benefit of their members.

Anti-corporate activists, then, argue that MNCs interfere in the political process. But in this, MNCs are no different from non-governmental organisations (NGOs), political parties, elites, and other well-placed individuals. Where anti-corporate activists believe that MNCs are most damaging, however, is as a result of their immense economic and political bargaining power. ${ }^{13}$

Certainly, they have enormous wealth at their disposal, possess superior technology, and are able to utilise the intellectual and legal powers of the best negotiators and lawyers. ${ }^{14}$ In addition to this, bilateral and multilateral trade regimes clearly favour MNCs. The Multilateral Investment Guarantee Agency (MIGA) and the Overseas Private Investment Corporation (OPIC) also favour the interests of MNCs. Wells and Ahmed (2007) are forthright in their view that the power of these organisations to support the interests of MNCs is significant. Spagnoletti and O'Callaghan (2011) also note the extent to which the Political Risk Insurance (PRI) industry underpins a great deal of MNC activity in the developing world, albeit at an enormous cost to the insured companies.

One of the most often cited examples of an MNC interfering in the political process of another country is the role that International Telephone and Telegraph (ITT) played in the overthrow of Chilean President Salvador Allende in the 1970s (Sampson, 1973).

Allende was a democratically elected leader who had a socialist agenda for his country. When elected, one of the first political decisions he made was to nationalise the assets of a number of American MNCs, including Kennecott Copper and ITT. ${ }^{15}$ The latter pressured the United States (US) government to overthrow Allende and have its assets returned. With support from ITT and Kennecott Copper, the Central Intelligence Agency (CIA) engineered a coup to remove Allende from power. During the coup, Allende reportedly committed suicide, and a fascist military junta came to power that was favourable to US interests. 
The Pinochet regime turned out to be one of the most repressive in Latin America. ITT had a direct hand in removing a democratically elected president and, as a consequence, fostered 28 years of tyranny in Chile. ${ }^{16}$

A more recent example is Chevron's lobbying of the American Congress in 2005 to stop the China National Offshore Oil Corporation's (CNOOC) bid to acquire the Union Oil Company of California (Unocal). CNOOC wanted to purchase Unocal because of its large footprint in Asia. Chevron wanted to acquire the company for much the same reasons. Chevron used its influence to persuade the House of Representatives and President George W. Bush Jr that the CNOOC bid threatened America's energy security. The resulting negative press led CNOOC to withdraw its bid for the company and this, then, paved the way for Chevron to buy Unocal for US\$18.4 billion in stock and cash (Mouawad and Barboza, 2005). The amount was considerably lower than the CNOOC offer.

Anti-corporate activists often draw a link between MNCs and the subversion of democracy within home countries as well. This is a particularly controversial issue in the US, where the relationship between politicians and MNCs is very close. Bendell and Kearins (2005: 374) highlight the problem of political lobbying by MNCs. According to them, this includes the financing of political campaigns, threats to relocate their industries offshore, contributions and gifts to well-connected public figures, and the provision of funding to peak industry bodies. Toyota's funding of the American Automobile Manufacturers Association's campaign to stop a law requiring all new passenger cars achieve a 35 miles to the gallon efficiency is a good example of this practice. In addition, almost one-third of the members of the US Defense Policy Board are representatives of large American MNCs, such as Lockheed Martin and Gulfstream Aerospace. Given the emphasis that the US places on democracy, anti-corporate activists worry that this close (perhaps cosy) relationship undermines the democratic process. Jewell (2004: 138-9) offers an interesting approach to this question. He has developed a chart he calls 'USA, Inc.' that shows the linkages between defence MNCs and individuals in government. It shows a complex web of linkages and relationships between companies, the White House, Congress, the CIA, the Pentagon and, interestingly, Saudi Arabia. Jewell argues that: 'the threat that corporations pose to our democracy is clear. The tapestry of government/corporate influence illustrated by U.S.A. Inc. is not a democracy of the people. It is not the democracy envisaged by our forefathers' (Jewell, 2004: 137). ${ }^{17}$ Bakan (2005: 95) makes the same point in a slightly different way. He argues that '[c]orporate America's long and patient campaign to gain control of government ... is now succeeding'. 


\section{They Abuse Human Rights}

Anti-corporate activists argue that MNCs are also responsible for significant human rights abuses. ${ }^{18}$ Concern about the link between the activities of MNCs and human rights abuse is not new. The early colonial trading companies were notorious for their disregard of human rights, with slavery being the most obvious example.

In recent years, a number of high-profile court cases in the US involving MNCs and human rights abuses have brought the issue to the attention of the public (Muchlinski, 2001: 31). These cases followed a US court decision to allow protest groups to use the Alien Torts Statute to litigate against American companies for their activities in foreign jurisdictions. Business Week has called this statute a 'milestone for human rights' (Business Week, 2005; Kurlantzick, 2004). The statute allows foreign litigants to seek financial damages in the US courts. A Colombian Labour union brought a lawsuit against Coca-Cola for allegedly employing a paramilitary group that killed union organisers (Leech, 2001). ${ }^{19}$ Unocal found itself in a similar position during the construction of a US $\$ 1.2$ billion pipeline through a remote part of Myanmar (Burma) (Benson, 2000). Opposition from local villagers and a refusal to work on the infrastructure project led to military intervention. Allegations of murder, torture, rape and forced labour surfaced. Human rights groups were continually refused entry into the country to verify the truth of these claims. While Unocal denied any wrongdoing, the statute provided a legal basis for a lawsuit brought against the company by 15 unidentified villagers (Wells, 1998). ${ }^{20}$

A second suit brought against the company by the National Coalition Government of Burma and the Federation of Trade Unions of Burma claimed damages on behalf of all Burmese who had suffered human rights abuses as a consequence of the project. Once again, Unocal denied wrongdoing and stated publicly that it did not know that there were human rights abuses taking place. However, the judge in the case was not convinced by this argument, finding that it was almost inconceivable that the company did not know that human rights abuses were occurring. A number of MNCs had already pulled out of the country, citing human rights abuses as the main reason for leaving. ${ }^{21}$ Unocal eventually settled the lawsuit out of court (Eviatar, 2005). Regardless of whether or not the company was unfairly treated by the courts, the case demonstrates how human rights issues have become a major problem for MNCs.

No case has done more to highlight the questionable behaviour of MNCs than Nike's use of sweatshop labour to produce its footwear in the late 1990s (Klein, 2001: 405-21). Investigations carried out at a number 
of plants in Cambodia, Indonesia and Vietnam revealed that Nike was paying below minimum wages and requiring staff to work long hours under oppressive conditions. In Cambodia, many Nike subcontractors were also found to be employing children. What made the situation worse was that while Nike was paying its workers just a few cents an hour, it was at the same time paying famous athletes millions of dollars to advertise its products. In addition, as Schwartz and Gibb (1999: 51) point out, 'Nike boss Phil Knight's 1994 salary was US\$1 500000 . On current wages, a young woman in China churning out his shoes would have to work nine hours a day, six days a week for 15 centuries to match that'. Consequently, Nike became the subject of global protests by human rights and labour organizations. Indeed, for a number of years, protestors conducted an 'International Day of Action Against Nike'. ${ }^{22}$ The most visible and lasting memory of these protests is the 'swooshstika', a combination of the Nike swoosh and a swastika. This is meant to demonstrate that Nike acted in a way reminiscent of the Nazis during the 1930s and 1940s, when they press-ganged European Jews, Poles and others into labour camps. ${ }^{23}$

It is probably the case that most MNCs have, at some time or other, violated the human rights of their workers and those of the people living in communities around their operations. This is especially true in the extractive industries (Handelsman, 2002; Orellana, 2002) ${ }^{24}$ Sometimes the abuses have stemmed from Western arrogance and a lack of cultural sensitivity for the rights of indigenous peoples. It is only recently that traditional communities have begun to receive compensation for the use of their lands by mining companies. Anti-corporate activists believe that almost all MNCs have a bad record on human rights. Few MNCs have explicit statements about respect for human rights in their codes of conduct. The determination of activist groups like Human Rights Watch and Amnesty International suggests that there will be continued pressure on MNCs to improve their human rights record in the future (Arnold, 2010; MacDonald, 2011; Wettstein, 2010).

\section{They Destroy the Environment}

Climate change is the accelerated warming of the Earth as a direct result of human activity. This warming is caused by the release of substantial amounts of carbon dioxide, methane and other greenhouse gases into the atmosphere, as a consequence of industrialisation, fossil fuel use, changing land usage and agricultural practices, and deforestation. If left unchecked, climate change has the potential to impact humankind profoundly on a global scale, exacerbating poverty and underdevelopment, and contributing 
to the destruction of entire communities. Stern (2007: xv) warns that the basic requirements for life are at risk as the Earth warms. Access to food and water may be affected, negatively impacting health standards. Further, changes in the environment could make parts of the world uninhabitable. As the Earth's temperature increases, glaciers will melt, leading to rising sea levels and a growing incidence of flooding. This is estimated to affect one-sixth of the world's population, particularly those living in the Indian subcontinent, parts of China, and the Andes region of South America. It is also likely to lead to the widespread displacement of communities (Stern, 2007: 65). Droughts in some areas, particularly Africa, will lead to a reduction in crop yields, thus resulting in food shortages and starvation. The economic burdens of inaction against climate change are equally intimidating, with the costs potentially amounting to 5 per cent of GDP annually, or 2 per cent if a broader range of risks are factored in (Stern, 2007: Xv). These are just some of the potential adverse impacts of climate change and, consequently, every country stands at a climate change crossroads. Experts warn that this is a time for prompt, calculated decision-making, not bureaucratic inertia (Garnaut, 2008: 20; Flannery, 2009).

Climate change is only one aspect of the problem. Particle pollution cloaks many cities and towns in dense, acrid smog that affects the health and well-being of millions of people. ${ }^{25}$ According to the World Health Organization (WHO), as many as 2 million people a year die prematurely as a consequence of air pollution. ${ }^{26}$ Acid rain is eating away at historic and architecturally significant buildings and monuments. Reckless and unsustainable agricultural practices are leading to deforestation, habitat loss, and the extinction of animal, insect and plant species. Overfishing is reducing fish stocks, making it difficult for some coastal communities to feed themselves. Equally concerning is the fact that deforestation is also leading to creeping desertification, with around 12 million acres of farmland becoming unproductive deserts annually (Holtz, 2007).

According to anti-corporate activists, the major cause of our environmental crisis is the activities of large MNCs. These companies are the largest emitters of greenhouse gases (GHGs). The top ten polluting companies produce more than a billion tons of greenhouse gas annually. More open than most, Royal Dutch Shell reported in 2011 that the company had emitted 74 million tonnes of greenhouse gas into the atmosphere (Royal Dutch Shell, 2011d). In their 2013 sustainability report, greenhouse gas emissions totalled 73 million tons (Royal Dutch Shell, 2013). When we consider that this is the result of one company's operations, it is not difficult to consider the end result of over 77000 companies and their affiliates polluting the environment. 
Not only are MNCs the largest emitters of GHGs, anti-corporate activists charge that they are irresponsible emitters. They continue to pollute the environment even though they understand the consequences of their actions. Monsanto knew that its polychlorinated biphenyl (PCB) plant in Anniston, Alabama, was poisoning the local environment (and residents) for more than 40 years. ${ }^{27}$ An internal memo showed that the company kept the problem a secret for many years (Beiles, 2000). After the US Environmental Protection Agency ordered them to clean up the site, the company was found to have interred millions of tonnes of PCB waste into the hillsides around its plant. As Barlett and Steele (2008) note, 'the old Monsanto plant remains one of the most polluted spots in the US'. ${ }^{28}$

Pollution is an industrial by-product of our modern lifestyle. As a consequence, we are all to blame to some degree. However, the issue becomes sinister when companies hide the fact that they have poisoned the environment and actively seek to prevent people from knowing the truth. One of the notorious examples of this approach was the formation of the Global Climate Coalition in 1989. Its members included some of the world's most significant polluters, including British Petroleum (now BP), DuPont, Exxon, Ford Motor Company, General Motors Corporation and Shell Oil USA. The purpose of the coalition was to mount a campaign to challenge the veracity of climate science and global warming, for purely commercial advantage. ${ }^{29}$ At its height in the mid-1990s, the organisation spent more than US\$1 million on consultants and US $\$ 100000$ a year lobbying politicians and developing public relations strategies to combat climate science. ${ }^{30}$ However, the companies soon realised that membership in the coalition undermined their already fragile reputations and most left the organisation. In 2001, the coalition became defunct (Hoffman, 2001; Gewin, 2002).

According to anti-corporate activists, corporate irresponsibility extends to 'pollution havens' as well (Grether and Melo, 2003; Fullerton, 2006). ${ }^{31}$ In order to escape the high cost of maintaining environmental standards at home, anti-corporate activists argue that MNCs sometimes move their operations to places that have low or non-existent environmental standards. The argument is that these MNCs move their operations to developing countries because host governments are more willing to tolerate environment degradation in order to gain much-needed investment. In this way, companies escape the need to reduce the polluting effects of their operations in their home country and the regulatory burden that goes with it.

Perhaps the issue that concerns anti-corporate activists the most is the recent trend among MNCs to paint themselves as environmentally 
friendly actors. Anti-corporate activists refer to this as 'greenwash'. This tactic is seen as little more than a shallow attempt to convince the public that buying their products is an environmentally sensible thing to do. To achieve this, companies use the language of sustainability and corporate social responsibility. But, according to anti-corporate activists, there is little tangible evidence to suggest that many of the world's largest polluters are actively working to reduce their emissions. Consequently, the much-needed change, according to activists, cannot occur while MNCs are privileged economic actors. As Hawken (2005: 3) argues, '[s]tanding in the way of change are corporations who want to continue worldwide deforestation and build coal-fired power plants ...'.

\section{They are Making the World Culturally Uniform}

The impact of MNCs on the environment is easy to document. Oil spills, deforestation and polluted rivers all leave tell-tale signs. They also tend to receive extensive coverage in the media. However, determining whether, and to what extent, MNCs affect local cultures and traditions is a much more difficult undertaking: not least because cultures are 'lived'. As such, they are dynamic and adaptive and, over time, local, regional and international pressures influence them. No culture is now, or has ever been, immune from change. Furthermore, MNCs are only one force exerting pressure on various cultures.

Culture refers to the ways in which people make their lives meaningful (Tomlinson, 1999: 18). A culture is made up of a number of attributes. These include language, histories, stories and traditions, customary practices, ideals and norms of behaviour, ethics and law, religious practices, and symbols. While these attributes give meaning to people's lives, they also orient them along a continuum between their past and future. To some extent, culture determines where individuals locate themselves in the social and spiritual world. Accordingly, it performs a critical function in human development. It is also the glue that binds communities together.

But anti-corporate activists argue that MNCs undermine the cultural traditions of the countries in which they operate. First, they weaken cultural diversity because they are making the world more culturally uniform. This is leading to the creation of a new American-style global culture. Second, the cultural goods and services sold by these companies are often identified with the home country, regardless of where they are produced. Coca-Cola and Pepsi are uniquely American, just as Peugeot and Renault automobiles are French. Third, while corporate advertising campaigns are designed to sell products and services, they are inevitably 
advertisements for particular cultural values and practices. When Nike employed Michael Jordan to sell its shoes, American basketball increased in popularity around the world. Young males in Australia, the United Kingdom and elsewhere began to dress in NBA singlets, watch American basketball games, and aspired to be like Jordan. In other words, these campaigns changed young people's perceptions and preferences. Fourth, when backed by global marketing campaigns, Western cultural products are inherently seductive. Many young people, especially teenagers, see them as status symbols. Often, too, young people both in the global North and South see these products as liberating and a sign of affluence. Finally, the language of MNCs is traditionally English and, as Drohan and Freeman (2000: 429) note, 'the English juggernaut is often blamed for the death of minority languages'.

Barnet and Cavanagh (1996:74) argue that it is not just the interaction between MNCs and traditional cultures that is a problem, or even the products and services that they sell. Rather, it is the sheer volume of cultural goods flowing into local communities that undermines cultural diversity. According to them, MNCs, especially those in the entertainment industry, crowd out locally produced film, television and music. The giant media and entertainment MNCs have been able to use new digital technologies to heighten the profile of their products in host markets. Moreover, there are often more American cultural goods being consumed in non-American markets than local products. The presence of these MNCs acts as a medium through which American cultural values are being articulated and spread globally.

There is a range of data that potentially highlights just how embedded American culture is around the world. Starbucks has more than 16000 stores worldwide; Coca-Cola products are advertised and sold in more than 200 countries. In 2009, McDonald's had more than 30000 local restaurants in 118 countries. American banking giant Citibank has offices in over 100 countries and more than 200 million customers worldwide. Viacom, the world's largest entertaining company, has a media presence (motion picture, television mobile phone, and online platforms) in over 160 countries and territories. Viacom Media Networks have over 200 locally programmed and operated television channels across the globe, in regions such as Western and Eastern Europe, Russia, Africa and Latin America. In September 2012, the company's flagship music programme, MTV, was available to 600 million households (Viacom Inc., 2012). If you add the entertainment content of the other five major players in the entertainment space, it is easy to see why critics worry about the loss of cultural diversity. ${ }^{32}$ Consequently, Barnet and Cavanagh (1996: 75) warn that local cultural practices and traditions are in danger of being lost. 
The feeling that world culture will be degraded if diversity is lost is widely shared among artists, cultural conservatives and nationalists. Yet these concerns are overwhelmed by the sheer power of global popular culture, which threatens local cultural traditions and the traditional communities from which they spring.

The dominance of global popular culture gives rise to concerns about homogenisation and cultural imperialism. As American MNCs are the leading suppliers of these 'goods', it is their values that are being 'imposed' upon local communities, whether these communities want them or not. The American sociologist Herbert Schiller once described this as 'homogenized, North Atlantic cultural slop' (Tomlinson, 1999: 81).

\section{SEATTLE AND AFTER: SHOWDOWN OR SLOWDOWN?}

These four criticisms lie at the heart of the anti-corporate activist critique of MNCs. While they are not in themselves new criticisms, they have taken on a new sense of urgency for activists as a consequence of globalisation. This has been an important driver of MNC growth around the world. But, as these companies have become more powerful, opposition to them has grown. Concern about the behaviour of MNCs manifested itself most visibly at the anti-globalisation protests in Seattle on 30 November 1999. ${ }^{33}$ Tens of thousands of protestors converged on the city to protest against the growing power of MNCs, globalisation and unfair trade arrangements between rich and poor countries.

Not since the Vietnam War has there been such a groundswell of opposition to a set of public policy issues. Indeed, the World Trade Organization (WTO) conference had to be cancelled. ${ }^{34}$ The response from some of the attendees was predictable and dismissive. Michael Moore, the Head of the WTO at the time of the riots, called the protesters selfish protectionists unconcerned about the world's poor (cited in Klein, 2002a: 3). Other politicians incredulously asked how anyone could argue that globalisation was not beneficial to both rich and poor nations.

Seattle ushered in a new era of protest (Rikowski, 2001; Cockburn et al., 2000). What is interesting about this latest form of activism is that its character was very different to that of the 1960s protest movement. That movement was generational in character. For progressive young people living at that time, the institutions, policies and values of their leaders had failed them. The Cold War had brought them precipitously close to a nuclear holocaust and the US and Australian governments were sacrificing their young men and women in an unwinnable war in Vietnam. As Roszak (1970: 46-7) commented at the time: 
[i]n an historical emergency of absolutely unprecedented proportions, we are that strange culture-bound animal whose biological drive for survival expresses itself generationally. It is the young, arriving with eyes that can see the obvious, who must remake the lethal culture of their elders and who must remake it in desperate haste.

Inspired largely, but not exclusively, by socialist values, these political activists sought to remake the world by attacking social and sexual conservatism, racial intolerance, the unequal treatment of women and minority groups, conformism, and the war mentality of Western policy makers.

A very different kind of protest movement emerged in Seattle, although the urgency was the same as earlier protest movements. It symbolised the beginning of a global movement opposed to the power of MNCs. Coming together under the umbrella of the Direct Action Network (DAN), the 50000 or so protestors represented 'an emerging species of political organization based on networks, rather than institutions' (De Armond, 2000). Various participant groups mobilised using cell phones, police scanners and wireless laptops. Walkie-talkies continually fed information to protesters operating in and around the downtown area. Much of this information was also uploaded to the Internet, and became available to millions of people around the world, who sought to draw inspiration from the protests.

So diverse was this movement that Crossley (2002: 674) questioned whether it was appropriate to call it a movement at all. Instead, he suggested that it is better described as a 'protest field'. It was also a slightly more flamboyant and theatrical movement than the counter culture of the 1960s. Boyd (2000) describes the Seattle protests as a 'costume ball'. At the time, both Newsweek and The Economist highlighted this with pictures of sea turtles and people dressed as Santa Claus staring down riot police. Irreverent parodies of US presidents also added a sense of theatre and art to the movement. Indeed, it gave it a sense of spontaneity, vibrancy and optimism for the future..$^{35}$

None of this apparent gaiety and diversity should gloss over the fact that Seattle was a very violent confrontation between police and protesters. The police used tear gas, concussion grenades, $\mathrm{CN}$ gas, pepper spray and rubber bullets in an attempt to quell the crowd. By most accounts the police were quite vicious, bludgeoning people whether they were protestors or not (Cockburn et al., 2000: 13-52). Even some legitimate WTO delegates were targeted by police and beaten.

Protestors were also violent in response to police brutality. The Black Bloc anarchists came armed with hammers and crowbars ready to 
vandalise shop fronts and damage property, especially those of MNCs like GAP. Moreover, the Seattle police claimed they were pelted with stones, glass bottles and Molotov cocktails.

In all, some 500 people were arrested. Retailers estimated that the riot caused about US\$20 million in property damage and lost sales. Furthermore, it led to the resignation of the Chief of Police, and the Mayor of Seattle failed in his subsequent bid for re-election in 2001.

The Seattle protest movement, also known as N30, had an enormous impact on the protest movement as a whole. First, the protest represented a new beginning for anti-corporate activists. Second, it also drew attention to the WTO, a relatively unknown international institution. Indeed, the turmoil in Seattle became something of a curse for the WTO. Since N30 new agreements on trade and investment have been dogged by failure. The Doha round only agreed to a new agenda for discussion. This agenda subsequently broke down in Cancun, Mexico, amid further protests and a revolt from developing countries participating in the talks. Third, it emboldened the protest movement globally. The N30 protesters were successful in their protests in Seattle and continued their efforts at a number of follow-up protests at International Monetary Fund (IMF) and World Bank meetings, and at meetings of the World Economic Forum (WEF). Fourth, it was really the first anti-capitalist movement of modern times. As Rikowski (2001: 2) notes: 'it was against capitalism as a way of life'. Fifth, while it is true that the protests were broadly anti-capitalist, there were deep ideological divisions between the protesters. However, Cockburn et al. (2000: 65) seem to suggest that it was the street 'warriors' who won the Battle for Seattle, not the various labour unions and liberals in attendance. Put differently, the battle was won by the anti-corporate left. Finally, and perhaps most importantly of all, it demonstrated how new communications technologies could be used to connect people in multiple locations, not just around the Seattle area during the riots, but globally as well.

The euphoria of the 'victory' in Seattle is evident in a number of publications that followed the event. According to Nace (2005: 200), N30 was a 'blossoming' of opposition to corporate power. Danaher and Mark (2003: 18) describe the occasion as the 'rebirth of an American anticorporate movement' and 'a coming-out party for a movement long in gestation'.

Perhaps the author who most embodies the sentiment of the protesters in Seattle is Naomi Klein. Klein has written for a range of newspapers including, The Guardian, the New York Times and Canada's Globe and Mail. She is also published in academic journals, such as the Socialist 
Register (2002b). Klein is a committed radical and is staunchly anticorporate and anti-capitalist. Her well-publicised book No Logo appeared a year or so after the Seattle riots. While the book is focused mainly on the impact of corporate branding on communities, especially in the US, it is also an articulation of many of the issues that activists were voicing at Seattle. As one reviewer of the book concluded, 'This is a book to galvanize the resistance that began at Seattle' (Mertes, 2000). Klein's subsequent book Fences and Windows is an interesting exploration of the values and goals of the new anti-corporate/anti-capitalist movement.

Over the last ten years, Naomi Klein has received numerous awards for her work, and is now largely a full-time political activist. In 2011, she attended the 'Occupy Wall Street' (OWS) rally and gave a speech to the protestors. In that speech, she referred to their protest as 'the most important thing in the world now'.

One of the things Klein shares with many other activists is a perception that a showdown between MNCs and anti-corporate activists is imminent. ${ }^{36}$ If, by 'showdown', is meant a confrontation between opposing sides that leads to some ultimate resolution, it would appear that this has not yet materialised, and may never do so. Certainly there is a plethora of alternative radio stations and Internet sites in existence that are broadly anti-corporate, and there have been some examples of direct protest and resistance around the world. As we noted earlier in the chapter, the protests in Bolivia against the privatisation of water is a good example (Olivera and Lewis, 2004; Polet, 2007). In addition, the World Social Forum (WSF) provides an important space for dialogue between various activist groups. So important is this forum that Chomsky (2004: 236) once described it as a 'second superpower' and suggested that it showed considerable promise in bringing about positive change. There are also many academic studies which target aspects of MNC behaviour, as well as celebrating the virtues of political resistance (Willis and Hardcastle, 2004; Amoore, 2005). But there does not appear to be any visible momentum at present, especially if we consider the 1999 Seattle protests as the high water mark of the latest wave of anti-corporate activism. This does not mean that the anti-corporate movement is a spent force, only that the early optimism of Klein and others appears to have dissipated over the past few years, rhetoric to the contrary. OWS is hardly a movement with any real capacity to effect broad social or economic change, especially at the global level.

There are a number of reasons why the change they desire so much has not materialised. The coordinated attacks on the World Trade Center on 11 September 2001 changed the global political landscape and the priorities of national governments everywhere. A discourse about the 
evils of globalisation and MNCs gave way to one dominated by the war on terror, personal and national security, and why the tragedy happened to the US.

Put differently, the anti-corporate activist agenda was supplanted by a different set of political issues and problems. First, the American Left were quick to blame the United States for the attacks. Sontag (2001) noted in The New Yorker, '[w]here is the acknowledgement that this was not a "cowardly" attack on "civilization" or "liberty" or "humanity" or the "free world" but an attack on the world's self-proclaimed superpower, undertaken as a consequence of specific American alliances and actions'. Similarly, in a public lecture at the Massachusetts Institute of Technology (MIT) a few weeks after the attacks, Chomsky (2001: 35) delivered a lecture titled 'The new war against terror'. He argued that America had it coming because it had been practising terror on a global scale for more than 100 years. He stated that we 'can think of the United States as an innocent victim only if we adopt the convenient path of ignoring the record of its actions and those of its allies ...'.

Chalmers Johnson (2004) refers to this viewpoint as 'blowback'. According to him, the CIA first used the term in a briefing document in the $1950 \mathrm{~s}$, referring to the consequences that followed from certain courses of action. In 1953, the CIA helped to overthrow the Mossadegh Government in Iran and return the Shah to power. ${ }^{37}$ This, in turn, led to a quarter of a century of tyranny and oppression. The Shah was once again removed from power by Ayatollah Khomeini and other religious clerics. This, in turn, led to the Tehran hostage crisis (Buchan, 2013). The theory holds that September 11 was the unintended consequences of decades of American imperialism. It symbolised the collective anger of peoples and states around the world that had suffered, and are still suffering, at the hands of successive US governments.

At a time of national tragedy, however, such arguments seemed to many to be callous and unpatriotic and, once again, showed the political mainstream why left-wing activists had little to contribute to serious public and foreign policy debate (Flynn, 2004). As Kazin (2002: 42) pointed out at the time, '[i]t's difficult to think of any radical or reformer who repudiated the national belief system and still had a major impact on U.S. politics and policy'. As a result, activism lost some of its credibility during this period. This weakened the anti-corporate movement significantly.

The wars in Iraq and Afghanistan further muddied the waters for activists. Debate raged about whether or not Saddam Hussein had weapons of mass destruction, rather than intense scrutiny about whether Halliburton and other large MNCs were entitled to lucrative contracts to 
support US operations in Iraq and in Afghanistan. ${ }^{38}$ Perhaps the most obvious point to make is that despite numerous protests against the war, mass opposition to it soon dissipated after the fighting had started. Despite the failure to find weapons of mass destruction, the growing body count, numerous congressional and senate inquiries, and ongoing carnage from suicide bombers, George Bush Jr, Tony Blair and Australia's Prime Minister John Howard were all returned to power in subsequent elections. Indeed, Bush and Howard increased their majority in government. ${ }^{39}$ That President Aznar of Spain lost the 2004 election had more to do with the timing of the bomb blasts in Madrid. Had those blasts not occurred, most electioneers in Spain predicted that Aznar would have been returned to power as well (Luttwak, 2004).

Finally, the Global Financial Crisis (GFC), the state of the American economy, unemployment, Hurricane Katrina, and the BP oil spill in the Gulf of Mexico tended to overshadow issues relating to globalisation and MNCs. It is not that these issues went away exactly, as much as changes in the global political landscape impacted on the anti-corporate message. Only with the OWS did some fire return to anti-corporate activism.

On a more practical note, it is difficult to see how a global 'showdown' could emerge out of a movement that is, by and large, anarchic and decentralised. Cohesion is important for coordination. Indeed, this is a lesson that Lenin learned from the failure of nineteenth-century anarchism to bring about a revolution in Europe. The Vanguard Party was Lenin's solution to the shortcomings of decentralised protest. This suggests, then, that there is a high degree of wishful thinking in the writings of those who have posited a possible confrontation between anti-corporate activists and MNCs that would lead to a restraining of their power, or other similar outcome.

Two years after Seattle, and in the wake of the collapse of Enron, some journalists were beginning to question whether the enthusiasm for protest by these activists had dissipated. Writing in The American Prospect, Penniman (2002) asked:

[w] hy hasn't the moment been seized? It's been almost a year since Enron evaporated and two years since the 'new economy' lost its giddiness. But where's the grass-roots ground swell? What happened to all of those daring anticorporate protestors who paralysed Seattle during the World Trade Organization meeting?

Two years later, The Economist (2004a) also reported that the movement was faltering because of a range of organisational and ideological problems, including apathy amongst the rank and file, a breakdown 
between various factions, and a lack of attendance at meetings. Somewhat cheekily and cynically, the well-known magazine argued that:

Given that the anti-globalization movement has lent ideas to capitalism - at the mushier end of corporate social responsibility, for instance, where fear and conscience meet to try to placate the mob - capitalism should surely return the favour in anti-globalization's dark days. There are plenty of modern management techniques which the movement could employ to reinvigorate itself. Has it, for instance, tried benchmarking itself against comparable movements? If street protest is too arduous for the membership, should it not think of outsourcing its more strenuous activities to the immigrants who already do most of Britain's tougher jobs. Taking that argument further, if domestic apathy is the problem, perhaps the answer is offshoring. A Mayday protest organized in, say, Libya or North Korea would really make a splash.

It is unclear whether the hype surrounding the rise of the anti-corporate movement was ever going to deliver the kind of economic reforms that these activists desired. Walker (2005: 699) once described anti-corporate activists as 'mosquitoes on the evening breeze, irritants to those who claim maturity and legitimacy at the centers of political life'. If such a movement can only ever be an 'irritant' to those in power, it is difficult to see how these activists can fulfil their long-term aspirations to remake the global economy and reign in the power of MNCs.

It is also a fact that many of the larger organised protests groups have been steadily losing members, rather than gaining them. Greenpeace membership has fallen from a high point of nearly 5 million members to approximately 2.8 million. Moreover, the number of protesters turning up to WTO and WEF meetings appears to be dwindling as well. Rather than an increase in opposition to MNCs, the opposite appears to be the case. The mass protest movement which was born in Seattle may have all but run its course.

The final point to make with respect to the anti-corporate movement losing momentum in the aftermath of September 11 is that their entrenched dislike of MNCs has meant they have not been able to see what is taking place around them. Zadek (2001: 1-2) observes that many of the '[a]ctivists leading the assault on corporate power and influence have in the main remained entrenched in their negative critique'. Anticorporate activists paint a picture that is too black and white. While there are companies who greenwash their image, there are as many who are genuine about balancing social and environmental imperatives with profit maximisation. We will examine the efforts of Interface Inc. in this regard in Chapter 6. Their efforts to become a sustainable enterprise have been celebrated as a model for the future of capitalism. ${ }^{40}$ Thus, it is not the 
case that MNCs cannot get beyond greenwash and marketing. On the contrary, it is the success of the early anti-corporate movement in shaping current MNC behaviour that has brought about an ideational shift in business thinking. What began as a campaign against MNCs by anticorporate activists demanding change has increasingly come to frame and instantiate new norms of corporate conduct.

Largely in response to the anti-corporate activist agenda, the literature on corporate social responsibility and the future of business has grown dramatically since the Seattle riots. Zadek (2001: 13) argues that '[c]orporations can be civil', while Parker (2002: 30) speaks about the possibility of an 'open corporation' that is strongly committed to corporate social responsibility. Hopkins (2003: xii) predicts that soon 'it will not be possible to conduct business without being socially responsible'. Finally, Vogel (2005: 162) argues that there is now a 'market for virtue'. While this is not definitive evidence, it is clear that a growing number of writers are pointing to the emergence of a different kind of MNC. While anti-corporate activists continue to be mired in a negative critique, the movement is likely to continue to lose momentum. Thus, the much anticipated 'showdown' appears to have turned into a 'slowdown'. The anti-corporate movement has been extremely successful in effecting change in the behaviour of MNCs. This is not simply because of their capacity for protest, but because they have turned corporate reputation into a political issue, subsequently exposing the Achilles heel of all modern MNCs. However, they now find themselves in a bind. On the one hand, they have been successful in achieving a significant degree of ideational change in MNC behaviour through the strategic use of political power yet, on the other hand, they cannot accept their success in modifying that behaviour (Spar and La Mure, 2003).

None of this is to suggest for a moment that activists do not have other avenues to attack MNCs. This includes an explosion in the number of websites devoted to anti-corporate themes. Some examples of these include the Multinational Monitor, Mines and Communities and Corporate Crime Reporter. Other sites offer more targeted critiques. These include sites that are devoted to attacking specific MNCs like Nike and Nestlé, as well as those targeting specific social and political issues. ${ }^{41}$ Moreover, The New Internationalist continues to provide a wellestablished voice in magazine form, and has been doing so since the early 1970s. So while organised protest appears to have dissipated, the activists' agenda continues to be articulated with gusto. MNCs would be well advised not to backslide on their evolving social and environmental credentials as a consequence. 


\section{INTERNATIONAL INSTITUTIONS AND MNCS}

Anti-corporate activists are not the only force in international relations (IR) exerting pressure on MNCs. International institutions such as the $\mathrm{UN}$, the Organisation for Economic Co-operation and Development (OECD), and other agencies are having an influence in this regard as well. Through a range of institutional frameworks and partnerships, these organisations are attempting to improve the contribution of MNCs to society and to development.

One of the first initiatives of this kind occurred in 1973. In the middle of 1972, the UN Economic and Social Council asked the SecretaryGeneral (SG) to examine the role of MNCs in the development process, as well as assess their impact on IR. The SG appointed an Eminent Persons Group to consider the matter. A report titled Multinational Corporations in World Development (United Nations, 1973) was provided to the group to facilitate the work. The group recommended the establishment of a special commission on MNCs. The UN Centre on Transnational Corporations (UNCTC) began work in 1974, guided by three broad objectives:

1. To further the understanding of the political, economic, social and legal effects of TNC activity, specially in developing countries [sic];

2. To secure international arrangements that promote the positive contributions of TNCs national development goals and world economic growth while controlling [and] eliminating their negative effects; and

3. To strengthen the negotiating capacity of host countries, in particular developing countries, in their dealings with TNCs.

The UNCTC lasted for almost two decades and was eventually absorbed into a newer commission, more broadly devoted to international investment. However, the underlying rationale remained the same for the successor organisation; that is, to promote investment in the developing world, while reducing the negative impacts associated with MNC activity.

The most recent attempt to engage MNCs is the United Nations Global Compact (UNGC). The concept of the Compact originated within the office of the former UN Secretary-General Kofi Annan (1999). In a speech to the WEF, Annan argued that the global economy remained vulnerable to a range of threats and suggested that MNCs could contribute to reducing threats that might emerge in the future.

In July 2000, the UNGC was launched in New York. Present at the launch were representatives from some of the world's largest MNCs, NGOs and members of the trade union movement. The UNGC is both an acknowledgement of the contribution that MNCs have made to global 
economic growth, but that it needs to focus more explicitly on human rights, labour issues, the environment and corruption.

The UNGC has two main objectives. The first is to embed its core principles in MNC thinking globally. The second is to get MNCs to support the broader UN agenda, particularly the Millennium Development Goals (MDGs) and now, the newly developed Sustainable Development Goals (SDGs). At the heart of the Compact are ten core principles covering four areas of importance. These are:

\section{Human Rights}

1. Businesses should support and respect the protection of internationally proclaimed human rights;

2. make sure that they are not complicit in human rights abuses.

\section{Labour}

3. Businesses should uphold the freedom of association and the effective recognition of the right to collective bargaining;

4. the elimination of all forms of forced and compulsory labour;

5. the effective abolition of child labour;

6. the elimination of discrimination in respect to employment and occupation.

\section{Environment}

7. Businesses should support a precautionary approach to environmental challenges;

8. undertake initiatives to promote greater environmental responsibility;

9. encourage the development and diffusion of environmentally friendly technologies.

\section{Anti-corruption}

10. Businesses should work against corruption in all its forms, including extortion and bribery.

The UNGC is not a regulatory body, and has no power to compel MNCs to abide by these principles. Adherence to the principles is on a voluntary basis only. According to Ruggie (2002: 23) the UNGC is best viewed as a 'social learning network'. It is a site for various groups to engage with each other and work together to achieve mutually beneficial goals. It does this in three ways: through international sharing and learning, policy 
dialogues, and partnership projects. In March 2004, 1366 formal corporate participants were involved in the activities of the Compact. Today, there are around 10000 corporate participants. In a review of its performance in 2004, McKinsey \& Company (2004: 2) concluded that '[o]ur impact assessment has found that the Global Compact has had noticeable, incremental impact on companies, the UN, governments and other civil society actors and has built a strong base for future results'. In the 2011 annual review, the UNGC had added a further 1861 new companies to the initiative. This seems to suggest that it is a positive vehicle for the promotion of change in corporate behaviour (United Nations Global Compact, 2011).

The OECD has also moved in this direction. The organisation has developed its own set of principles, contained in the OECD Guidelines for Multinational Enterprises (2000: 9). These guidelines take the form of recommendations from governments to $\mathrm{MNCs}$ in order to bring harmony between corporate activities and government policy, to strengthen relations between MNCs and the societies in which they operate, to improve the foreign investment climate, and to contribute to sustainable development.

Inevitably these, and other similar institutional initiatives, appear to critics as a palliative, rather than a concerted effort to curb the behaviour of MNCs. Critics have accused these initiatives of providing a basis for MNCs to 'blue wash' their dishonest activities (Oldenziel, 2005: 12). But, most importantly, the key problem that anti-corporate activists have with these approaches is that they lack credible accountability and enforcement mechanisms. Zadek (2001: 84-9) summarizes the criticism in the following way. First, companies can gain reputational value in being associated with these institutions, but do not actually have to change their behaviour. Second, companies are able to avoid being more heavily regulated by national governments by associating with the UN. Third, the legitimacy of globalisation remains intact. In the final analysis, it is legislation and regulation anti-corporate activists want, not partnerships and multi-stakeholder dialogues.

Ruggie argues that voluntary approaches by themselves will not satisfy everyone or provide an adequate solution to global governance issues. But he argues that 'these company-based initiatives are significant not only for what they achieve directly, but because they are also triggering broader second-order consequences' (Ruggie, 2002: 25). Most importantly, they demonstrate that a 'global public sector' (Ruggie, 2002: 26) is emerging. He defines this as an: 
institutionalized arena of discourse, contestation, and action organized around the production of global public goods. It is constituted by interactions among non-state actors as well as states ... The effect of the new global public domain is not to replace states, but to embed systems of governance in broader global frameworks of social capacity and agency that did not previously exist (Ruggie, 2004: 519).

Ruggie offers a few examples of this but the main point he is making is that the relationship between states, non-state actors and MNCs is changing, and new forms of governance are emerging. Arguments about the inherent weaknesses in international partnerships and voluntary codes miss this important point. They also fail to take account of the importance of the corporate reputation to MNCs today. How activists have brought corporate reputation into the political debate about the behaviour of MNCs is the topic I turn to now.

\section{THE 'POLITICISATION' OF THE CORPORATE REPUTATION}

A number of business advocates have clearly understood the link between anti-corporate activism and corporate reputation, with Peters (1999) being one of the first. Others have also noted the connection. Albrecht (1996: 18-19) warns that '[t]he activists who protest at your doorstep will have a very vocal agenda - publicity for their cause, the need to express their anger over what they feel is corporate greed or apathy, and the desire to create change through the infliction of real pain or other media-generated discomfort'. Larkin (2003: 18) argues that activism 'is an established feature of modern day society and must be factored into reputation risk planning'. Similarly, Alsop (2004: 45) bluntly notes that '[i]gnoring activists can be dangerous'.

Over the years, activists have used a number of methods to undermine MNC credibility and their activities. Perhaps the worst example of this is tree-spiking. Advocated by Earth First, it involves activists deliberately inserting metal spikes into trees to prevent them from being harvested. Attempts to harvest spiked trees with chainsaws had the potential to seriously injury or even kill forest workers.

People for the Ethical Treatment of Animals (PETA) is also known to advocate violence against MNCs who test their products on animals. PETA has been responsible for destroying animal testing laboratories and liberating caged animals. In the US, where they are headquartered, PETA has been accused of being a domestic terrorist organisation. Their 
signature mode of protest has included naked men and women advertising their cause. In this, they have been heavily supported by celebrities such as Alicia Silverstone, Charlize Theron and Pamela Anderson. ${ }^{42}$

King (2000: 2) argues that the purpose of these activities is to humiliate MNCs in order to undermine their reputations. ${ }^{43}$ As noted earlier, this is based on shaming MNCs or by influencing consumer and investor behaviour. This strategy has led to a 'politicisation' of the corporate reputation. ${ }^{44}$ While not the most eloquent of terms, the notion that corporate reputations have become 'politicised' provides an important insight into the shift in the bargaining relationship between anticorporate activists and MNCs. Further, as King (2000: 2) notes:

the contest over corporate reputation includes, but goes beyond issues surrounding the implementation of technology and workplace reforms to incorporate business ethics, environmental sustainability, community involvement, corporate governance and community development. It is a contest that has stimulated the rephrasing of questions about the responsibilities of business in society: What are corporations for? What is the extent of their fiscal, social and environmental responsibilities? To whom are corporations accountable?

King's argument is that, as corporate reputations have become a more significant part of the success of MNCs, this has exposed them to the political power of anti-corporate activists. Put differently, the increasing importance of the corporate reputation to MNCs has weakened their bargaining position and made them more vulnerable to activist pressure. It means that reputational capital is put at risk whenever an MNC finds itself in the cross-hairs of anti-corporate activists' gun sights. ${ }^{45}$

How has this occurred? One way of thinking about this issue is through the social amplification of risk framework (SARF). It offers an interesting account of this process. ${ }^{46}$ The SARF concept seeks to account for the way risks are communicated across societies and institutions. At its heart is the idea of social amplification. When risks are communicated through any medium, such as face to face, within the workplace, or through the media, SARF suggests that two things occur. First, these risks tend to be amplified as they are transmitted. Second, the potential exists for ripple effects to occur. These may have secondary and tertiary impacts that grow beyond an original risk event and interact with a wide range of psychological, social, institutional, or cultural processes in ways that intensify perceptions of risk and its manageability' (Kasperson et al., 2003: 13). The strength of SARF is its ability to describe how risk signals, in the form of images, stories, signs and symbols, are received and transmitted to a range of social agents. These signals pass through 
so-called 'amplification stations' (Kasperson et al., 2003: 15). They filter and interpret the information, which then leads to particular responses from participants in the social system. Amplification stations include an array of individuals and groups within society, including activists, government agencies, communities and politicians. However, in SARF, the media is the primary amplifier.

In essence, anti-corporate activists have been adept at communicating and amplifying risks. They have been able to gain maximum exposure for their causes in various media by highlighting the risks that MNCs pose to human well-being. The media, then, is a primary amplifier of the real or perceived risks. The ripple effects of amplification travel across borders and around the world. The Seattle riots are an excellent example of this phenomenon.

There are numerous other examples that highlight this phenomenon. Many people fear being attacked/eaten by a large shark. Yet the reality is that they are more likely to get badly injured or killed in their home than attacked and killed by a shark. When a shark attack occurs, it generally makes headline news. This tends to heighten our awareness of the danger of shark attacks, well out of proportion to the real danger these creatures pose to humans.

Fear is a crucial ingredient in the amplification process. Anti-corporate activists are very skilled in the use of rhetorical language to heighten community fears about MNCs. I have referred to this elsewhere as the 'rhetoric of moral outrage' (O'Callaghan, 2007b: 197). The purpose of such rhetoric is not objectivity or truth, but to paint a dire picture of the state of the world, a picture so bleak that it will shock individuals and push them to mobilise against MNCs. Chomsky is one of the best exponents of this strategy, although it is a common style of argumentation of those at the extreme ends of the political spectrum.

Whatever the academic merit of this approach to argumentation, it is difficult for MNCs to counter. The Achilles heel of most corporate leaders is that they are generally politically naive. A comment from Monsanto's Director of Corporate Communications illustrates the point: 'Monsanto should not have to vouchsafe the safety of biotech food. Our interest is in selling as much of it as possible. Assuring the public safety is the Fed's job' (Starr, 2000: 9). Given the community's concern, real or imagined, about the possible dangers of genetically modified (GM) foods, such a rash statement does nothing to enhance Monsanto's reputation as a responsible company, or improve public perception of GM foods. Indeed, it is this sort of comment that activists seize upon to show that MNCs are uncaring and that they should not be trusted. Astoundingly, this person is a communications 'expert'. 
What this suggests is that many corporate managers are at their weakest where anti-corporate activists are at their strongest. The latter are by nature political animals. They are socially, politically and culturally aware, and have no trouble outflanking unreflective corporate managers. When this political astuteness is coupled with a capacity to amplify risks and heighten community fears, it is a force to be reckoned with.

\section{CONCLUSION: TOWARD CORPORATE SELF-REGULATION}

Anti-corporate activists' pressure has led to MNCs seeking to improve their performance on social and environmental issues, but it is important not to lose sight of the fact that MNCs have shown a willingness to adjust to this new reality. The various means by which MNCs are expressing this commitment should not be interpreted as an attempt by these companies to appease public opinion while protecting their profits. Rather, the shift in their behaviour represents a genuine ideational shift in the thinking of corporate managers. This shift is pushing them towards corporate self-regulation. It is a long journey, but one which many MNCs are embarking on. Some are further along the road than others. Some have just begun the journey. Still others do not fully appreciate what is at stake. Over the next decade or so, no MNC will be able to do business without taking responsibility for their social and environmental footprint, or adding significant value to the communities in which they operate.

\section{NOTES}

1. For an earlier version of this argument see O'Callaghan (2007b).

2. Erin Brockovich is, perhaps, the most notable example. See Brueckner and Dyann (2010); Perlman (2004).

3. Dangl (2007) argues that the popular protests in Bolivia began with a confrontation between local miners over access to mine leases and then spread to a violent confrontation regarding access to water in Cochabamba. As he (2007: 8) notes, '[t]he residents of Cochabamba rose up when the multinational Bechtel Corporation bought their public and communal water systems. In a classic example of the failure of the privatization of a basic resource, the company's rate hikes and exclusive water rights sparked a revolt that continues to rock the country's social and political landscape'. Also see Barlow and Clarke (2002: 154-80).

4. These include ethical codes of conduct, targeted philanthropy, citizenship programmes, employee development and equity programmes, and new social and environmental reporting initiatives.

5. Hereafter referred to as 'Shell'.

6. A transaction cost economics perspective sees the impact of the pressure exerted by activists on MNCs in a slightly different way. It is not a concern with reputation, but the 
cost of doing business. Using their example of a pharmaceutical company selling drugs into developing countries, Vachani et al. (2009: 448) argue that activism can 'result in high transaction costs for the MNE as it is forced into a public relations campaign to address accusations of attempting to exploit developing-country customers, as well as incur legal and lobbying costs of dissuading the local government from sanctioning local manufacture of generic drugs. These escalating transaction costs can change the balance of costs and benefits of the pricing policy, forcing the MNE to change strategy and seek new governance mechanisms to implement a differential pricing strategy'. On this view, the change in behaviour is driven by transaction costs, rather than concerns with corporate reputation.

7. The term 'business advocate' is used here to refer to authors who seek to advocate on behalf of business interests. This may be in matters of corporate strategy and governance, advice on how to meet particular challenges, or simply to show how business can perform better. In the case of Peters, the main aim of his book is to demonstrate to MNCs how they can protect their reputation from anti-corporate activists.

8. These authors follow in the footsteps of, among others, Barnett and Cavanagh (1976; 1995) and Falk (1999).

9. They are also referred to as multinational enterprises (MNEs), transnational corporations (TNCs), and firms.

10. Many anti-corporate activists are also staunch anti-Americans. I leave that controversial issue aside here, as I am interested in anti-corporate activist views about MNCs, not the foreign policies of successive US governments. The most comprehensive treatment of anti-Americanism is O'Connor (2007).

11. The obsolescing bargain (OB) is an interesting theoretical concept. Developed by Vernon (1971), the concept highlights the dynamic bargaining relationship between MNCs and host governments, within a particular investment cycle. A developing government needs investment. It offers a contract to an MNC to build a new utility. This might be to construct a new power station, a sanitation plant, or a transportation network. Initially, the host country is a beggar. It needs investment and so is willing to offer the winning MNC lucrative conditions to invest. These may include tax holidays, low tax rates and other concessions. After the investment is established and has become profitable for the MNC, the host government wants a greater share of the profits from the investment. Gradually, the government changes the regulations governing the investment. Over time, the original bargain obsolesces. The project loses its value and becomes unprofitable. The result is that the MNC may leave the project. On the various aspects of this idea see Spagnoletti and O'Callaghan (2011); Grosse (2005a).

12. This issue is treated in more detail in Chapter 4, where I examine Shell's rationale for not supporting the release of the Ogoni Nine.

13. See Grosse (2005b); Eden and Appel Molot (2002); Fagre and Wells, Jr (1982).

14. According to Sell (1999: 172), the impetus for the Trade Related Aspects of Intellectual Property Rights (TRIPS) accords came from the CEOs of 12 large American MNCs. 'In effect, twelve corporations made public law for the world'.

15. One of the best discussions of this period is Moran (1974). See also Harmer (2011).

16. A similar story can be told of the United Fruit Company's role in supporting a coup in Guatemala in the 1950s. The long-term consequence of this coup also led to many years of repression and hardship for the Guatemalan people. See Schlesinger and Kinzer (2005).

17. This is also the central theme of Hartmann's (2007) book on the demise of the middle class in America.

18. These include the exploitation of workers, financial support for militia groups that torture and kill innocent people, inadequate attention to the welfare and safety of employees, forced removal of locals from traditional lands, and collusion with unscrupulous host governments.

19. See the website 'Killer Coke' (n.d.). 
20. Doe v. Unocal. See also Spar and La Mure (2003); Dale (2011). Human Rights Watch (2012) has recently stated that Burma's military are as violent as ever and the opening up of the country in the last two years has done little to improve the country's human rights record.

21. These include PepsiCo and French oil company Total S.A.

22. See the website 'Boycott Nike', accessed 8 August 2015 at http://boycott-nike.8m.com/. See also Sage (1999).

23. For critiques of MNCs' labour record see Armbruster-Sandoval (2005); Locke et al. (2009); Williams et al. (2014).

24. Mining companies have improved their behaviour in host countries. See the Mining, Minerals and Sustainable Development (MMSD) project, located within the International Institute for Environment and Development (IIED). A range of position papers have been developed within the institute to help mining companies navigate their host country relations and their environmental and social obligations. The International Council on Mining and Metals (ICMM) has a similar function.

25. This has been a particular problem for the automotive industry. See also Paterson (2000); Kolk and Levy (2004); Paterson and Dalby (2006); Paterson (2007); Mikler (2009); Orsatto and Clegg (1999: 264).

26. World Health Organization 'Air quality and health' (n.d.). A large percentage of these deaths occur in the family home due to smoke inhalation from biomass and kerosene cooking fires. See Spagnoletti and O'Callaghan (2013).

27. Polychlorinated biphenyl is an industrial coolant.

28. Monsanto was one of the first companies to openly challenge the findings of Rachel Carson's Silent Spring. The company tried unsuccessfully to have the book banned (Carson, 2002; Stauber and Rampton, 1995: 123-42).

29. The release of a number of reports by the UN's Intergovernmental Panel on Climate Change (2007) (IPCC) triggered the formation of the coalition.

30. The vast majority of scientists think that the climate science modelling is accurate. For a defence of climate science see Flannery (2009). On climate scepticism see Paltridge (2010); Kehr (2011); Robinson (2013). Also researchers from the Lavoisier Group refute the science of human-induced climate change, and criticise the policy responses proposed by the Rudd and Gillard Governments in Australia. See Evans et al. (2009).

31. The so-called 'pollution haven' hypothesis has been a hotly debated topic among environmentalists over the last two decades. However, most commentators now appear to agree that the hypothesis is not proven. Mani and Wheeler (1997) argue that an examination of data over a 30-year period appears to show that pollution havens are as transient as low-wage havens. Smarzynska and Wei (2001) reach a similar conclusion.

32. These are The News Corporation, The Walt Disney Company, Time Warner, Sony Corporation of America, and NBC Universal.

33. Often called N30 by activist groups.

34. The organisation was formally known as the General Agreement on Tariffs and Trade (GATT).

35. In Seattle, there were intellectuals, socialists, anarchists, environmentalists, human rights activists, land reform groups, women's groups, gay and lesbian networks, farmers, religious groups, animal rights activists and politically engaged musicians.

36. This theme is most thoroughly discussed by Barlow and Clarke (2001). The title of the book is Global Showdown: How the New Activists Are Fighting Global Corporate Rule.

37. On the rise and fall of the Shah, see Saikal (2009).

38. On the history of Halliburton, including its activities in Iraq, see Briody (2004).

39. These were not just three members of the so-called 'Coalition of the Willing'. Other members included Afghanistan, Albania, Azerbaijan, Bulgaria, Colombia, the Czech Republic, Denmark, El Salvador, Eritrea, Estonia, Ethiopia, Georgia, Hungary, Italy, Japan, South Korea, Latvia, Lithuania, Macedonia, the Netherlands, Nicaragua, the Philippines, Poland, Romania, Slovakia, Spain, Turkey and Uzbekistan. Two points are worth making about the list. First, the number of official participants in the coalition had changed 
considerably by 2006, as some governments bowed to domestic pressure to exit the conflict. This was particularly the case with Spain. Second, while Kuwait, Bahrain and Qatar were used by the United States to prepare for the conflict, none were officially listed by the State Department as being members. See Shifferes (2003).

40. Holliday et al. (2002) and Arena (2004) offer some other examples of companies moving in this direction. Also see Mirvis et al. (2010); Seeger and Ulmer (2001).

41. These range from informing the media and the public about the activities of MNCs, handing out leaflets in public places, picketing corporate headquarters, publishing detailed anti-corporate reports, and publishing embarrassing photographs of environmental damage.

42. See Huffington Post (2011) slideshow.

43. Sasser et al. (2006: 4-5) refer to this political strategy as 'direct targeting'. As they note: '[d]irect targeting enables NGOs to exert maximum pressure on firms to join the NGO-preferred program'.

44. The concept of 'politicisation' is a term familiar to political theorists. It generally means two things. First, it refers to a revealing of the power relations inherent in a particular social construct. In this sense, feminists have 'politicized' gender. See Brown (2004: 116). A second usage of the term is when a particular issue moves from being a non-political issue to become a political one. Scruton (2007: 534) uses the example of Frankfurt School theorist Walter Benjamin, who advocated the politicisation of art in order to promote revolution in Europe. It is in this latter sense that the term is used here. It suggests that at one time corporate reputation was not seen as a political issue. The skill of anti-corporate activists is being able to turn it into one.

45. Reputation capital has been defined by Fombrun (1996: 11) as 'a form of intangible wealth that is closely related to what accountants call "goodwill" and marketers term "brand equity",.

46. An alternative explanation for the success of NGOs can be found in 'agenda setting theory'. See Ragas (2013). 